\section{DISCOURSE OF FEMININITY IN ADVERTISEMENTS IN THAI HEALTH AND BEAUTY MAGAZINES $^{1}$}

\section{Siriporn Phakdeephasook ${ }^{2}$}

\begin{abstract}
This paper aims to analyze the discourse of femininity in advertisements for products and services for women published in Thai health and beauty magazines by adopting Critical Discourse Analysis approach. The research questions are: 1) what is the ideology of femininity represented in these advertisements? and 2) what are the linguistic strategies used for representing these ideological concepts? It is found that these advertisements convey an ideology of 'desirable women' which consists of three related concepts; 1) Desirable features for women include slim and slender figure; youthful appearance; white, clear,
\end{abstract}

\footnotetext{
${ }^{1}$ This study is sponsored by the TRF-CHE Research Grant for New Scholar. I would like to express my gratitude to the Thailand Research Fund (TRF) and the Commission on Higher Education (CHE), Ministry of Education, for their benevolent support. I would like to thank Associate Professor Dr. Krisdawan Hongladarom, my research mentor, for her constructive research guidance and comments. Also, I would like to express my thankfulness to Assistant Professor Dr. Natthaporn Panpothong, Assistant Professor Dr. Carina Chotirawe, and the two anonymous readers for their insightful comments on this paper.

The original version of this paper was presented at the International Conference on Asian Folklore 2009. July 2-3, 2009, Bangkok, Thailand.

${ }^{2}$ Lecturer, Department of Thai, Faculty of Arts, Chulalongkorn University, Bangkok
}

and radiant skin; large, firm, and shapely bust; and odorless privates. These features are construed signs of "healthy beauty." 2) Some natural bodily conditions which are opposite to the desirable features are problems and enemies. Women with these "problems" are in trouble and lack confidence. 3) Bodily management can be done effortlessly and effectively through the magic of the advertised products and services. Thus, women should improve themselves to be better persons by selecting the right products and services. Various linguistic strategies are manipulated to represent these ideological concepts including the use of lexical selection, claiming common facts, metaphors, overstatements, rhetorical questions, presupposition manipulation, and intertextuality. As for lexical selection, positive words, as well as trendy terms such as "healthily beautiful" and "healthy", are selected to ratify the attributes to be construed as "desirable." Also, terms denoting problems and anxieties are used to describe some natural features, which are opposite to the "desirable" ones, as "undesirable features." Lexical choices denoting ease, short periods of time, and potency are used to describe the effectiveness of bodily improvement processes. Factual claims are adopted to validate ideological concepts. WAR metaphors are used to construe the opposite features as enemies with whom women are fighting against. Overstatement is used to describe the delightful feeling of achieving "desirable" features and the miraculous power of the advertised products or services. Presupposition manipulation is used to imply that some features are problematical, shameful, and even diseased. This further implies that women with what is deemed to be "undesirable" features are in trouble. The use of intertextuality in the form of 
inserted personal narratives and the citation of scientific facts quotation is used to suggest that the advertised products and services are the right ones for women.

\section{Introduction}

Gender is socially constructed rather than biologically given (de Beauvoir 1952, West and Zimmerman 1987, Lorber 2003, Barker 2008). In the case of femininity, Simone de Beauvoir (1949) states that "one is not born a woman, one becomes one." The process of becoming a woman is socially constructed. In the social construction of femininity, several social institutions such as family, school, and religion, create different sets of ideas or ideologies regarding the definitions, attributes, roles and rules of being a woman.

In most societies, including Thai society, the media also play a significant role in constituting and distributing ideological concepts of femininity. At present, owing to the increasing concern for health and physical well being in Thai society, which is in tune with global trends, health and beauty magazines have become more popular, as evidenced by the increasing number of such publications on the newsstands. Obviously, women are the main targeted readers of these magazines. It is therefore not surprising that the contents presented in these magazines are mostly targeted to a female audience including the advertisements for products and services specifically aimed at women. In order to promote sales of such products and services, the manufacturers and service providers make use of advertisements to provide information about their products and services. Inevitably, in the process of stimulating increased consumption of these products and services for women, some ideologies of femininity are constituted and represented in these advertisements in an attempt to influence readers, especially women.

This paper aims to analyze the discourse of femininity in advertisements for products and services for women in Thai health and beauty magazines. The approach and framework adopted is that of Critical Discourse Analysis (CDA) as developed by Fairclough (1992b, 1995) and Van Dijk (2001, 2003, 2006). The two research questions are:

1) What is the ideology of femininity represented in advertisements for products and services for women in Thai health and beauty magazines?

2) What are the linguistic strategies used to represent these ideological concepts?

This paper consists of four sections. In section 1, more details about the data and the approach used in this study will be provided. Next, an overview of the texts and discursive practice of advertisements of products and services for women will be presented in section 2. Sections 3 and 4 will be devoted to the analysis of the ideology constituted by the advertisements as well as the linguistic strategies adopted to construct such an ideology. In section 5, the socio-cultural practice dimension of the discourse of femininity will be discussed in order to sum up the findings.

\section{Data and approach}

The data used for this study was drawn from advertisements for products and services for women in six Thai health and 
beauty magazines, published between May 2008 and April 2009, including:

\author{
1. Health Plus \\ 2. Health Today \\ 3. Sukkhaphap Dee (Good Health) \\ 4. Shape \\ 5. Slimming \\ 6. Slim Up
}

These magazines were selected on the grounds that they were widely sold in different locations such as franchised bookstores, book and magazine sections in franchised convenience stores, local bookstores and bookstalls, which means that the magazines can reach an extensive group of readers.

Altogether one hundred and five examples of advertisements for products and services for health and beauty were gathered. These advertisements apparently target female readers. Two main criteria were used for data collection. First, models in the advertisements had to be female. Second, the term, phuuying (woman) needed to be mentioned in the advertisements.

\section{Concerning the approach to the study}

Critical Discourse Analysis (CDA) is considered the most appropriate approach for this research since it aims at analyzing ideologies constituted by discourse, especially public discourse and media discourse, and at unmasking the relationship between discourse and manipulation. Critical discourse analysis is a type of discourse analytical research that focuses on the way social power abuse, dominance, and inequality are enacted, reproduced, and resisted by text and talk in the social and political context. One of the ultimate goals of critical discourse analytical research is to expose and resist social inequality (Van Dijk 2003: 352).

Despite disciplinary differences among critical discourse researchers, their common main interest is in power, especially institutionally produced power. The purpose of CDA is to analyze the opaque as well as transparent relations between language and power in order to see the ways in which language/discourse is manipulated for producing and maintaining power inequality (Van Dijk 1993, 2003; Wodak 1995; Blommaert 2005). In so doing, CDA attempts to analyze how discourse is manipulated to constitute and represent ideology in favor of power dominance (Van Dijk 1993, 2006).

Among various frameworks in CDA, Fairclough's three dimensional framework has been widely adopted (Fairclough 1992a, 1995). According to Fairclough, language use is a communicative event consisting of three dimensions: namely text, discursive practice, and social practice. The first dimension, discourse as text, focuses on the linguistic features and organization of concrete instances of discourse (i.e., speech, writing, image, or a combination of these). The second dimension, discourse as discursive practice, involves the production and the distribution and consumption of the text. In this dimension, discourse is viewed as something produced, circulated, distributed, and consumed in society. The last dimension, discourse as social practice, concerns socio-cultural situations related to the production and distribution of the text, as well as influences upon the socio-cultural contexts caused by the text. It focuses on the roles of discourse in hegemonic process-how discourse is manipulated to control the minds of people 
in society (Fairclough 1995, Blommaert 2005, Van Dijk 2006). All three dimensions should be taken into account in order to achieve a thorough analysis.

\section{Previous studies}

Literature related to the present study can be discussed in three groups, namely studies on women or femininity in print media, studies on critical discourse analysis in Thai, and finally studies on critical discourse analysis focusing on gender or femininity. The last group which is directly related to the present study will be discussed in the most detail.

\section{Studies on women or femininity in print media}

Studies focusing on women or femininity in print media cover various research topics such as women's roles and their status as reflected in media (Sawasburi 1989), women's ideas presented in print media (Choosaengsri 1991), values and attitudes on gender as reflected in print media (Thamsarnsunthon 1994), women's images in print media (Kanjanaurairoj 1995), and values on beauty represented in print media (Pongudom 2005).

Most of these works are aimed at content analysis. Works analyzing linguistic strategies are Liwcharoenchai (2004) and Pongudom (2005). Liwcharoenchai analyzes linguistic strategies for giving advice in quizzes published in women's magazines in order to discern the features of "desirable" women and ideal persons. Pongudom adopts critical discourse analysis to analyze cosmetics advertisements in women's magazines in order to see the relation between language and beauty values.

\section{Studies adopting critical discourse analysis in Thai}

Research using critical discourse analysis as framework in Thai addresses different groups of data such as newspaper front pages and other columns (Hongladarom 1996, 2000, 2006), the discourse of Thai identity in various advertisements in Thai (Anantsuchartkul 2001), award-winning children's books (Wongbiasaj et al. 2006), magazine quizzes (Liwcharoenchai 2004), and cosmetics advertisements in women's magazines (Pongudom 2005). The research topics are varied including the identity of hill tribe ethnic minorities (Hongladarom 2000), beliefs regarding ideal persons and desirable women (Liwcharoenchai 2004), values of beauty as represented in cosmetics advertisement in women's magazines (Pongudom 2005), discourse of violence in the southern region of Thailand (Hongladarom 2006), ideology and power relations represented in award-winning children's books (Wongbiasaj et al. 2006), ideology in the advertising discourse of cosmetic surgery (Panpothong 2007), and ideology of smart consumers in advertising discourse of health-claimed products and services (Phakdeephasook 2007).

\section{Critical discourse studies on femininity as well as gender in Thai society}

Critical discourse studies in English on femininity, as well as gender, more generally are increasing (i.e. Chaudhuri 2001, Calasanti 2007, Crawshaw 2007, Soden 2008), while those in Thai are relatively lacking. Literature on critical discourse analysis that directly relates to the present study on ideology of femininity in women's magazine advertisements includes the following. 
Ponprateep (2000) analyzes the logics of consumption represented in the advertisement of health-claimed food supplements in Thai women's magazines and health magazines. Baudillard (1999)'s theory of the four logics of consumption is adopted as the main framework. It was found that the functional logic of usage values of health-claimed food supplements; i.e., the health benefits, was most prominently represented in the advertisements. The logic of sign value, the economical logic of exchange value, and the logic of symbolic exchange were also less frequently presented. In terms of the logic of sign value, food supplements were represented in relation to the concept of beauty. As for the logic of symbolic exchange, food supplements were defined as a gift of health concern. The economical logic of exchange value was rarely found in the advertisements. Several advertising techniques were used for presenting these logics of consumption. The technique that was mostly used was advertorial advertising. The advertisements functioned as rational motives rather than emotional motives.

Pongudom (2005) studies cosmetic advertising discourse in Thai in order to gauge the relationship between language and values of beauty in Thai society. It was found that cosmetic advertising discourses function to construct, emphasize, and express values of beauty. Cosmetic advertising discourse implies that women are beautiful only when they possess what is perceived to be features of perfect beauty. The concept of 'perfect beauty' represented by the advertisements is influenced by the Western model. Namely, "perfect beauty" means 'being young and healthy.' Moreover, these advertisements indicate that women are beautiful only when they use cosmetics to beautify themselves according to current fashion trends. The linguistic strategies used in these discourses can be categorized into two main groupssemantic strategies and pragmatic and discourse strategies. Semantic strategies include the use of verbs describing beauty, the use of intensifiers, and the use of words to negate non-beauty features. Pragmatic and discourse strategies include the use of figures of speech, claims, rhetorical questions, and presupposition manipulation.

Panpothong (2007) investigates the ideologies represented in the advertising discourse of cosmetic surgery adopting the approach of Critical Discourse Analysis (CDA). The findings reveal that cosmetic surgery has been redefined as a necessity instead of an optional process. Also, aging characteristics as well as some features of the oriental face are represented as deformities or diseases while cosmetic surgery is represented as a required treatment for better appearances. With the "magic" of cosmetic surgery, women can become beautiful in the way they desire, and forever maintain their youthful looks. In addition, this ideal beauty enables them to become successful in the modern Thai society. Various linguistic strategies, including lexical choices, presupposition manipulation, metaphors, narratives with direct quotations, etc, are exploited in representing these concepts.

It can be seen that there exist only a few studies on gender or femininity in Thai society adopting critical discourse analysis approach. None of them have analyzed discourse of femininity in advertisements for products and services for women in Thai health and beauty magazines. Therefore, it is anticipated that this present study will more or less help extend the 
scope of study of the critical discourse research on gender in Thai society.

\section{Traditional concepts of beauty and health in Thai society}

It is worthwhile and appropriate to take a look at traditional perceptions of beauty in Thai culture since it is more or less related to the concept of femininity in Thai society. The concept of Benchakanlayani (เบญูจกัลยาณี) 'women with five features of supreme beauty' often mentioned in Thai literature is considered a predominant traditional notion of beauty in Thai culture. The five beautiful features of Benchakanlayani include 1) phom ngam (ผมงาม) 'beautiful hair', 2) nue ngam (เนื้องาม) 'beautiful flesh', 3) kraduk ngam (กระดูกงาม) 'beautiful bone', 4) phiw ngam (ผิวงาม) 'beautiful skin', 5) wai ngam (วัยงาม) 'beautiful age'. To further clarify, to have phom ngam is to have a long and shiny black hair which when tied in bunch at the back of the head is look like the tail of a peacock. Nue ngam refers to pink and firm gums. Next, the indicator of kraduk ngam, which literally means 'beautiful bones, is white and even teeth. Phiw ngam means white radiant skin and black shiny skin. Last, wai ngam refers to youthful appearance (Khananulak 1981). It can be noticed that these features of beauty are mostly naturally given. Some of these, such as pink and firm gums and youthful appearance can be considered signs of good health. Hence, it can be said that the traditional concept of beauty is somewhat related to the concept of health. Nonetheless, these features were not termed "healthy beauty."

In addition to the concept of Benchakanlayani, according to
Chaisingkananont (2001), in traditional Thai society, a slim and slender figure, as well as white, spotless, and radiant skin, were considered features of standard beauty. Chaisingkananont (2001) argues that this notion of beauty was related to class distinction. That is, the socially dominant group tended to place high value on physical features mostly found among their members, namely slim and slender figure as well as fair and radiant skin. By contrast, those of the lower class who had to work hard outdoor generally tended to have a stout figure and dark complexion. These two features were construed as inferior.

It can be seen that, according to traditional concepts of beauty in Thai society, some desirable features were related to healthy physical features. However, they were not referred to as "healthy beauty." It seems that this term has been used to define these features recently.

\section{An overview of the advertisements of products and services for women in Thai health and beauty magazines}

Before launching out on an investigation of the ideology on femininity represented in the advertisements in health and beauty magazines, an overview of advertising discourse of products and services for women in Thai health and beauty magazines should be presented. In other words, this section deals with the text and the discursive practice of these advertisements while the social practice of these adverts will be discussed later in the last section. 


\section{The discursive practice}

In terms of discursive production, advertisements of products and services for women are produced by manufacturers as well as service providers apparently for commercial purposes. The manufacturers and service providers gain access to the production of advertising discourse and to the publication of health and beauty magazines which is a powerful communicative tool (Van Dijk 1993). This enables them to produce advertisements for their products and services and distribute these advertisements to the public through health and beauty magazines. These advertisements are aimed at introducing the products and services and persuading consumers to buy the products or use the services. As for persuasive ends, several tactics have been employed. One of them is to create the need and desire for the products and services by means of ideologies (Phakdeephasook 2007).

This is in accordance with Williams' (1980) argument that advertisements function to create consumers' desire and taste in the ways the manufacturers prefer. According to Williams (1980), advertisements directly serve manufacturers in manipulatively motivating consumers' desire and tastes to match the patterns designed by the manufacturers. In line with Williams (1980), Williamson (1978) points out that an advertisement does not simply provide information about the product. Rather, it simultaneously makes the product being advertised mean something to the consumers by using linguistic and symbolic codes.

The advertisements used as data in the present study are distributed in health and beauty magazines which are print media sold nationwide. Consequently, the advertisements can reach an extensive group of readers including healthconcerned female readers who are the potential customers. By association with other educational and/or medical discourses in the health and beauty magazines, these advertisements seem to gain more credibility.

\section{Characteristics of the advertising text}

The text of the advertisements for products and services for women in health and beauty magazines consists of both words and pictures. The words in the advertisements are used to present the products' and services' brand name, slogans, description and pieces of healthrelated information such as scientific facts, personal narratives about health problems and solutions. The pictures used in the advertisements mostly are illustrations of female presenters and products. In the advertisements of products for women, both the illustrations of the presenter and the product are featured. In the case of services for women's health and beauty, mostly pictures of the presenter are shown. Most of these presenters are female celebrities who are noticeably slender and physically attractive. Sometimes, the pictures of the service providers are also included in the advertisements.

According to Bernstein (1974 cited in Cook 1992: 10), two main types of advertisement are "reason ads" and "tickle ads." Reason ads aim to suggest motives for purchasing, while tickle ads appeal to the emotion, humor, and mood. Analysis shows that most of the advertisements of products and services for women in Thai health and beauty magazines tend to be of a hybrid nature - a combination between 
tickle ads and reason ads. That is, they tend to appeal to emotion and mood of the consumers as demonstrated by the use of large pictures of appealing presenters. However, health-related information, especially scientific facts, about the products and services is also provided as motives for purchase. This hybrid nature seems to dovetail with the hybrid attributes of health and beauty magazines which is a combination of women's magazines and health magazines. The following pictures illustrate the hybrid nature of these advertisements.

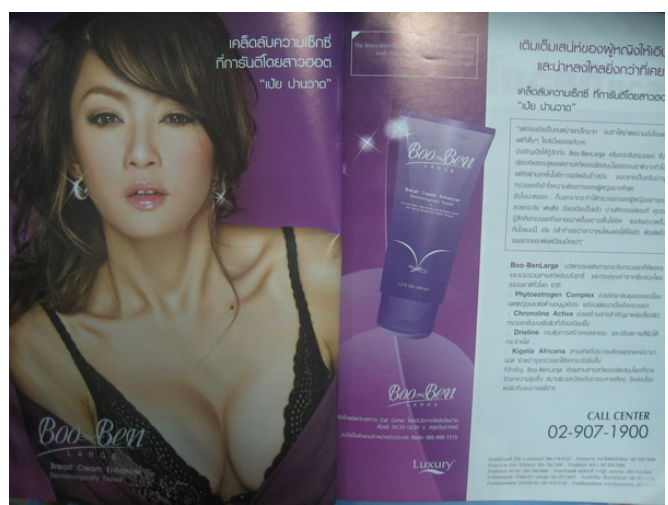

Picture 1: An advertisement for Boo-Ben Large breast enlarging cream (Health Plus, October 2008: 36-37)

In this picture, the large image featuring a sexy-looking presenter, who is an actress, is depicted in order to appeal to the mood and emotion of the readers. In the right hand side section, information including the presenter's personal narrative about her experience and comments about the product and scientific facts about the product ingredients is provided.

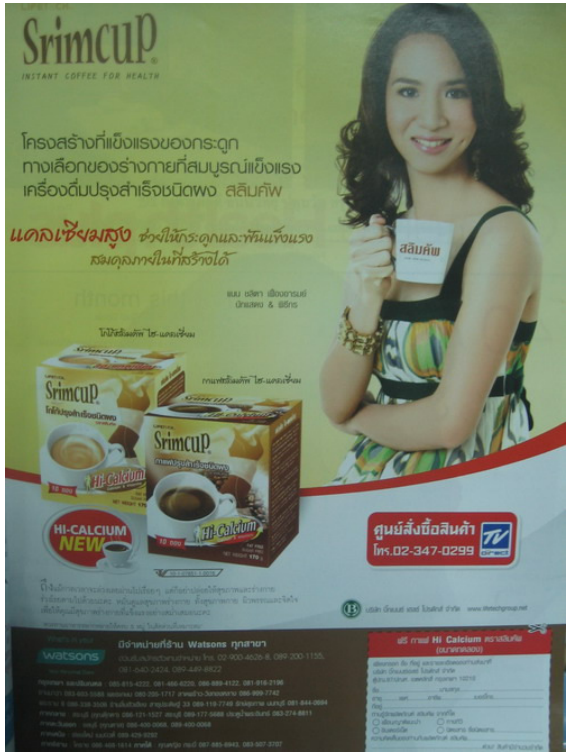

Picture 2: An advertisement for Srim Cup coffee (Slimming, September 2008: 31)

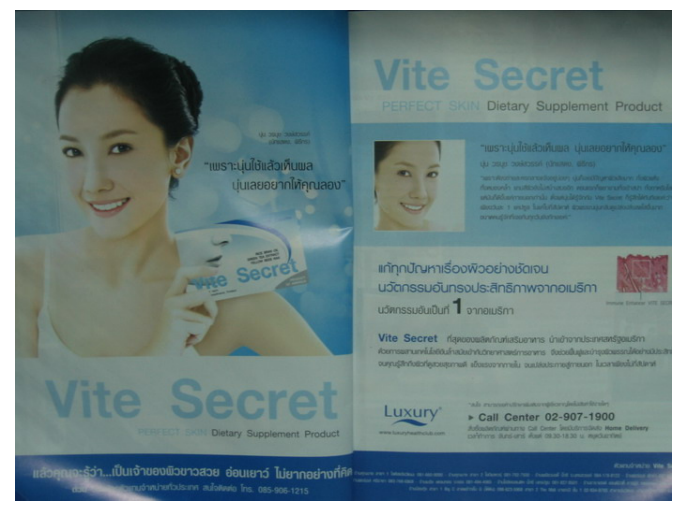

Picture 3: An advertisement for Vite Secret (Health Plus; November 2008: 18-19)

Pictures 2 and 3 also demonstrate the hybrid nature of trickle-reason advertisements found in the text of two products for women. Pictures of attractive presenters who are well-known celebrities are used to represent the prototype of women with good figures who are also endowed with beautiful and radiant skin. These pictures are accompanied by healthrelated information and a personal 
narrative about skin problems and solutions respectively in order to provide reasons for consumers to select these products.

The advertisements of health and beauty products and services appear in two main forms namely, advertising texts, as seen above, and advertorials. Advertorials are lengthy entries in magazines and newspapers which attempt to combine an article and an advertisement. The article section in the advertorials present seemingly "general" information on health and beauty issues. The advertisement section alongside gives specific information about the advertised products and services which can be related to the information provided in the article-section.

Picture 4, shown below, is an example of an advertorial. In this advertorial, an article on cellulite is presented in the column entitled "Sweet and Fit." Side-byside, an advertising text of "Fitnè low calorie sweetener powder for weight control" is presented. It can be seen that these two parts are closely related.

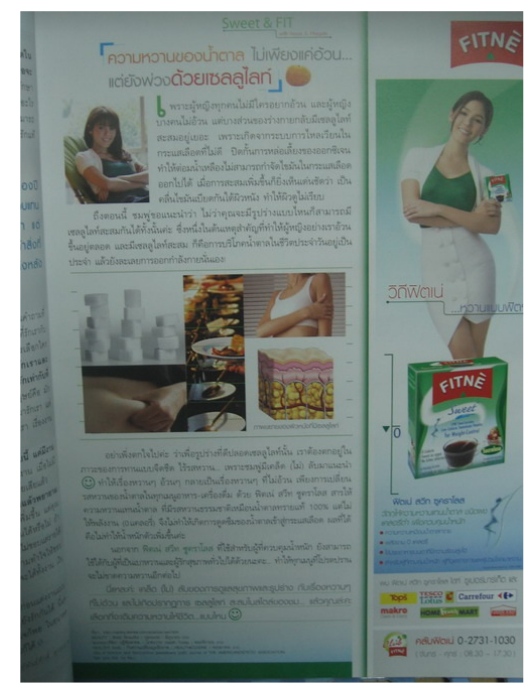

Picture 4: An advertorials for "Sweet and Fit" by Fitnè (Shape, August 2008: 31)

After providing an overall picture about the text of the advertisements of products and services for women in Thai health and beauty magazines, in the following section, the findings of the analysis of ideology of femininity will be presented.

\section{The ideology of femininity represented in the advertisements of products and services for women in Thai health and beauty magazines}

The analysis of the advertisements reveals that it is not only the information about the products and services but also concepts about women that are conveyed to readers. In other words, these advertisements function to constitute and represent an ideology of femininity or a set of ideological ideas about women, especially desirable ones, to readers in contemporary Thai society. The ideology constructed and represented in these advertisements consists of three related concepts.

1) Desirable features for women are a slim and slender figure; youthful appearance; white, clear, and radiant skin; large, firm, and shapely bust; and odorless hidden spot. These features are construed signs of "healthy beauty." These "desirable" features are what every woman wishes to attain since they make her feel confident.

2) Some natural bodily conditions which are opposite to the desirable features are problems, and enemies. Women with these "problems" are perceived to be in trouble and lacking in confidence. 
3) Bodily management can be done effortlessly and effectively owing to the miraculous power of the products and services for women's health and beauty.

Hence, women should make certain adjustments in order to improve their looks and be new and better persons by selecting the right products and services for themselves.

According to this ideology, it can be seen that all these "desirable" features pertain mainly to physical attributes. The intellectual and behavioral aspects, as previously emphasized in some Thai didactical literature and proverbs, are ignored. To be a desirable woman, one must be primarily good looking rather than anything else. Since it is very easy to become a desirable woman owing to the magic of health and beauty products and services, women should not simply limit their satisfaction to their natural but unsatisfactory bodily conditions. Therefore, bodily improvement is what women must undertake.

To sum up, the discourse of femininity in these advertisements defines the "desirable" features of women, creates anxiety for ordinary women and encourages these women to manage their bodily conditions in order to become better and more "desirable women." Definitely, bodily improvement is made possible by the products and services being advertised. Hence, it can be said that the construction and representation of this ideology is ultimately aimed to profit the manufacturers and service providers. In the next section, the linguistic strategies used to construct and represent these ideological concepts will be presented.

\section{Linguistic strategies used to constitute and represent the ideology of femininity in advertisements of products and services for women in Thai health and beauty magazines}

The ideological concepts about women represented in advertisements for products and services for women in Thai health and beauty magazines discussed in the previous section are constructed and represented by means of linguistic strategies. A linguistic analysis reveals that several linguistic strategies are used in constructing and representing this ideology such as lexical selection, metaphor, overstatement, rhetorical question, claiming, presupposition manipulation, and intertextuality. In this section, the linguistic strategies used in constructing and representing each ideological concept will be detailed.

\section{Concept 1: Desirable features for} women are slim and slender figure; youthful appearance; white, clear, and radiant skin; large, firm, and shapely bust; and odorless privates. These features are construed signs of "healthy beauty." These "desirable" features are what every woman wishes to attain since these features make her feel confident.

Linguistic strategies used in representing this ideological concept include the use of lexical selection, claiming, metaphor, and overstatement.

\section{Lexical selection}

Using positive words to ratify features construed as "desirable" 
Positive words such as ปรารถนา 'to desire', อยากมี 'to want/wish to have', ต้องการ 'to want, to need', มั่นใจ 'to be confident', ภูมิใจ 'to be proud of' are used with words or phrases denoting feature(s) such as รูปร่างดี 'good figure', ผอมเพรียว 'slim and slender', ผิวสวย 'beautiful skin', ความอ่อนเยาว์ 'youthfulness' in order to signify that they are "desirable" features for women. The following examples demonstrate the use of these lexical selection.

Extract 1: ผู้หญิงทุกคน “อยากมีรูปร่างที่ดี" เพื่อเพิ่ม ความมั่นใจให้กับตนเอง แต่ความสวยและความผอมมักมา กับอุปสรรคที่เอาชนะได้ยาก (Nature Gift coffee, Slimming, October 2008: 90)

Translation: Every woman "wants to have a shapely figure" to increase her selfconfidence. However, beauty and slimness usually come with obstacles that are difficult to overcome.

Extract 2: ...เพราะ “ความสวยอ่อนเยาว์” นั้นเป็นสิ่ง ที่สาวๆ ทุกคน “ปรารถนา"... (DHC Alpha Lipoic Acid and CO Q10, Sukkhaphap Dee (สุขภาพ ดี), September 2008)

Translation: ...Because "youthful beauty" is what every woman "desires" ...

Extract 3: ...ผู้หญิงทุกคนก็ "อยากมีผิวสวย" กันทั้งนั้น (Vite Secret, Sukkhaphap Dee (สุขภาพดี), June 2008: 18-19)

Translation: ...Every woman "wants to have beautiful skin."

In the above examples, the concurrence of these words and phrases leads to the interpretation that a slim figure, youthful beauty, and beautiful skin are desirable for women.

In the following two examples, breasts and private parts are construed as desirable female body parts.

Extract 4: เป้ยรู้สึกว่า “ทรวงอก” เป็น “เสน่ห์ที่ผู้ หญิง หวงแหนและน่าภูมิใจที่สุด” (Boo-BenLarge: Breast Enhancing Cream, Slimming, December 2008: 19)

Translation: I think that "breasts" are what constitutes a "woman's charm and attractiveness" and it is "something she should cherish and feel very proud of."

Extract5: เพราะผู้หญิง "ต้องการการดูแลจุดซ่อนเร้น" ที่ต่างกัน บีไนซ์ ผลิตภัณฑ์เพื่อจุดซ่อนเร้นจึงสร้างสรรค์ คุณค่าความอ่อนโยนให้คุณเลือก "ดูแลจุดซ่อนเร้น" ได้ครบ ครัน ทั้งสูตรน้ำแร่และน้ำนม ตอบทุก “ความมั่นใจ" ให้สาว ยุคนี้ (Be Nice, Slimming, October 2008: 19)

Translation: Because women "want different ways of taking-care of their private parts." Be Nice-feminine hygiene wash-creates a valuable gentleness allowing you to select the right way to take care of that special part, with both mineral water formula and milk formula. This product responds to every need for "confidence" on the part of today's women.

Using the trendy term สวย สุขภาพดี

'healthily beautiful' and สุขภาพดี

'healthy' to positively redefine the

"desirable" features

Due to health concerns in contemporary Thai society, the term สวย สุขภาพดี 'healthily beautiful' and สุขภาพดี 'healthy' have 
become fashionable. สวย สุขภาพดี is a new trend of beauty being promoted. In the advertisements, these two terms are used to create a new favorable definition for certain features, especially a slender and slim body, youthful appearance, and clear and radiant skin, as shown in the following extracts.

Extract 6: เคล็ดลับ “สวยสุขภาพดี” ง่าย มั่นใจ “ไร้ ส่วนเกิน"...(DHC Citrus Aurantium, Shape, October 2008: 11)

Translation: Tips for "healthy beauty." Effortless, Reliable, "No more weight problems."

Extract 7: นวัตกรรมขจัดไขมันล้ำยุค $\mathrm{CLS}$ “สวย เพรียว สุขภาพดี" (Cellu Loss Sculptor by Phillip Wain, Slimming, October 2008: 87)

Translation: CLS—cutting edge innovation for cellulite reduction, "Beautifully slender and healthy"

Extract 8: ล้างพิษแนวใหม่ เคล็ดลับ "สุขภาพดี หุ่น สวย หน้าใส" (Bio Grow DeyTox, Sukkhaphap

Dee (สุขภาพดี), January 2009: 73)

Translation: New way of detoxification. Tips for "healthy, beautiful shape, and clear complexion."

Extract 9: ด้วยการผสานเทคโนโลยีอันล้ำสมัยเข้ากับ วิทยาศาสตร์การอาหารจึงช่วยฟื้นฟูและบำรุงผิวพรรณได้ อย่างมีประสิทธิภาพจนคุณรู้สึกถึง "ผิวที่ดูสวยสุขภาพดี แข็งแรงจาก ภายในจนเปล่งประกายสู่ภายนอก”ในเวลาเพียง ไม่กี่สัปดาห์ (Vite Secret, Sukkhaphap Dee (สุขภาพดี), September 2009 : 1-2)
Translation: The combination of cutting edge technology and nutritional science helps effectively resuscitate and nourish the skin. So you can feel the "healthily beautiful skin-be healthy from within and shiningly radiant" in a few weeks.

In these extracts, "no more weight problems," "beautifully slender," "beautiful shape," "clear complexion" and "beautiful and radiant skin" are considered as signs of healthful beauty.

\section{Claiming common facts for women}

The terms ผู้หญิง 'women', ผู้หญิงทุกคน 'every woman', ผู้หญิงยุคใหม่ (modern women)," สำหรับผู้หญิง 'for women' are often used in order to claim that every woman wishes to attain "desirable" features. The following illustrations demonstrate the point.

Extract 10: ... "ผู้หญิงทุกคน" ก็ “อยากมีผิวสวย" กัน ทั้งนั้น (Vite Secret, Sukkhaphap Dee (สุขภาพ ดี), June 2008: 18-19)

Translation: ... "Every woman" wants to "have beautiful skin".

Extract 11: “ยุคนี้... “รื่องความสวยความงามสำหรับ ผู้หญิง” ต้องรวดเร็ว ทันใจ ตอบสนองความต้องการ ได้อย่าง รวดเร็วตรงจุดที่สุด 'Boo-BenLarge' ครีมกระชับและ ขยายขนาดทรวงอก ที่แม้แต่ดาราและนางแบบสาวสุดเซ็กซี่ 'เป้ย ปานวาด' ยังทึ่งและยอมรับในประสิทธิภาพที่เกินคาด" (Boo-BenLarge - Breast enlarging cream, Slimming, December 2008: 19)

Translation: Today... "beauty for women" must be quick and respond to each and every specific requirement. 'Boo-BenLarge' is a breast enlarging and firming cream that even Peuy Panwad, a sexy star and model, has been impressed 
and convinced by its extraordinary effectiveness.

In extract 10 , it can be construed that beautiful skin is what all women wish. Extract 11 implies that a large and firm bust is a desirable feature for women. By claiming that the concepts represented are common facts for women, the ideology represented sounds more convincing to readers.

\section{Metaphor}

In the following two examples, หุ่นสวย 'beautiful shape' and ผิวสวย 'beautiful skin' are the goals of a rhetorically military action. In other words, these features are what women should protect or fight for. The use of metaphor in these examples is indirectly related to the concept of 'healthy beauty'. That is, the features of 'healthy beauty' are construed a something women should try to achieve.

Extract 12: “ภารกิจพิชิตหุ่นสวย" (Nature Gift coffee, Slimming, October 2008: 90)

Translation: "Mission to conquer beautiful figure"

Extract 13: “ปฏิวัติผิวสวย” ... เผยผิวขาว เนียนในรูปร่างเพรียวกระชับ (Nu Vite, Health Plus, April 2009: 2)

Translation: "Revolution for beautiful skin"... reveal white, smooth skin on a slim and firm body

\section{Overstatement}

It is found that in the advertisements the euphoric feelings upon achieving more attractive features is often overstated. This implies that these features are desirable for women since attaining them could make them feel extremely elated.

Extract 14: "จะเกิดใหม่อีกครั้ง ไม่มีคำว่าเป็นไปไม่ได้" "เลิกฝันมานานแล้วค่ะ ว่าตัวเองจะกลับไปมีรูปร่างที่ผอม เพรียวเหมือนตอนเข้าวงการใหม่ๆ เพราะแอนพยายามลด แล้วหลายวิธีแต็กไไม่ได้ผลเพื่อนๆ เลยแนะนำให้เข้าไปที่ Kristie France ไม่น่าเชื่อค่ะว่าแค่ครั้งแรกก็เห็นได้เลย ว่าหุ่นเพรียวลง แถมยัง “ดูดีขึ้นจนตัวเองยังตกใจรู้สึกเหมือน เกิดใหม่จริงๆ ค่ะ คุณแอน วาสนา พูนผล/ ดารา นักแสดง (Kristie France, Slimming, December 2008: 79)

Translation: "Rebirth is not impossible." "I had stopped dreaming that I would become slim and slender like when I started my career. It was because I had tried several methods but they were all unsuccessful. Then, my friends recommended I visit Kristie France. It was unbelievable because from the very first time, my body became noticeably more slender. Also, "I felt that I had become so much more attractive that even I myself was amazed. I felt as if I was experiencing rebirth." (Wassana Poonphol/ actor)

Extract 15: “คืนชีวิตใหม่ . . . ให้ตัวคุณเลิกวุ่น . . . กับ ส่วนเกินตลอดไป" (Mind \& Care, diet program; Sukkhaphap Dee (สุขภาพดี), June 2008: 53)

Translation: "Regain a new life for yourself. Stop worrying about extra weight forever."

In these two examples, the experience of becoming slender is overstated and equated with the improbability of getting a new life. Also, this leads to the implication that being fat and overweight makes a woman's present life unbearable. 
Concept 2: Natural bodily conditions which are opposite to the desirable features are problems, and enemies. Women with these "problems" are in trouble and lacking in confidence.

Linguistic devices for representing this ideological concept include the use of lexical selection, presupposition manipulation, metaphor, and intertextuality. The use of these linguistic strategies are demonstrated and discussed below.

\section{Lexical selection}

Several strategies are used to define some natural features such as ไขมันส่วนเกิน ง cellulite', น้ำหนักส่วนเกิน 'overweight', ริ้วรอย แห่งวัย 'aging wrinkle', ผิวหมองคล้ำ 'skin with impurities and darkness', as problematical and anxiety-causing. First, terms denoting problem and anxiety such as ปัญหา 'problem', กังวล 'to be anxious', and ไม่มั่นใจ 'to be lack of confidence' are used to describe these features. Next, verbs implying problems and anxiety are associated with these "undesirable" features.

\section{Using terms denoting "problems, anxiety, lack of confidence" to negate some features construed as undesirable}

By using negative terms such as ปัญหา 'problem', กังวล 'to be anxious', and ขาดความ มั่นใจ 'to be lack of confidence' to describe some features such as มีไขมันส่วนเกิน 'to have cellulite', น้ำหนักส่วนเกิน 'overweight', ริ้วรอย แห่งวัย 'aging wrinkles', ผิวหมองคล้ำ 'skin with impurities and darkness', and อกหย่อนคล้อย sagging and drooping bust, these features are unfavorably construed as undesirable problems for women. The following extracts illustrate the use of this strategy.

Extract 16: Bustina ผลิตภัณฑ์ดูแลทรวงอก ที่มี คุณภาพและความปลอดภัยสูง ช่วยทำให้ทรวงอกกระชับ เต่งตึง อวบอิ่ม และเพิ่มความชุ่มชื้นให้กับผิวหนังของทรวง อก อีกทั้ง "แก้ปัญหาอกหย่อนคล้อย"ในเวลาเดียวกัน (Bustina, bust care product, Slimming, September 2008: 57)

Translation: Bustina, Bust care product of high quality and safety helps to firm and shape the bust, moisturize breast skin, and simultaneously "fix the problem of a sagging and drooping bust."

In this example, a sagging and drooping bust is defined as a problem that needs to be fixed by the combination of "ปัญหา" and "อกหย่อนคล้อย"

Extract 17: “ปัญหาเรื่องรูปร่างและส่วนเกิน" ใครบอก ว่า “แก้ไม่ได้"? อีกหนึ่งวิธีในการ "แก้ปัญหาส่วนเกิน" กับ สองผลิตภัณฑ์ ที่ตอบสนอง “ปัญหา" ได้ครบสูตร (Golden Life Coffee Srim and FiberryDetox, Health Plus, November 2008: 17)

Translation: Who said that "body shape and cellulite problems cannot be fixed"? Another way to "fix cellulite problems" is to use these two products that absolutely respond to "the problems."

Extract 18: “ความจริงเป้ยเป็นคน “หน้าอกเล็ก” ทำให้ “ขาดความมั่นใจ" เลยค่ะ..." (Boo-BenLarge: Breast enhancing cream, Slimming, December 2008: 19)

Translation: "In fact, I have a "tiny bust which affects my confidence and sense of self-esteem." 
Extract 19: "บอกลาความกังวลเรื่องริ้วรอยแห่งวัย" (Lamuca emollient, Slimming, September 2008:15)

Translation: "Say goodbye to the anxiety of aging wrinkles."

Using verbs implying "problem" or "undesirable condition"

Verbs such as กำจัด 'to get rid of', ขจัด 'to eradicate', ลดเลือน 'to reduce/ to eliminate', ชะลอ 'to suspend', ต่อต้าน 'to resist', แก้ 'to repair, to fix' and บอกลา 'to say goodbye', imply that the conditions being described are problematic or undesirable conditions. The fashionable phrase ต่อต้านความชรา 'antiaging' which is often used in the advertisements serves as an outstanding example. Also, extracts 16 and 17 above demonstrate the use of แก้ 'to fix, to repair' and extract 19 illustrates the use of บอกลา (to say goodbye). Some other examples are shown below.

Extract 20: “ชะลอการเกิดริ้วรอย”... คืนความอ่อน เยาว์สู่ผิวพรรณ (Avana Perfect Beauty Skin Collection, Slimming, December 2008: 49)

Translation: "Suspend the wrinkling process"... return youthfulness to the skin.

Extract 21: "ชะลอการเกิดการสะสมของไขมัน" ผิวพรรณผ่องใส่และนุ่มชุ่มชื่นอย่างเป็นธรรมชาติด้วย ProLachrystine A และ 3 Steps Chronotech ลิขสิทธ์เฉพาะของเอเอ็กซ์ทู เท่านั้น (axii Body control firming cream and Speed Chrono Shaping Cream, Shape, November 2008: 11)

Translation: "Suspend cellulite accumulation" making skin look naturally radiant, smooth, and moisturized by ProLachrystine A and 3 steps chronotech which are part of the exclusive formula of axii.

Extract 22: “ล็อคปัญหาไขมัน" (Siam Laser Clinic, Slimming July 2008: 9)

Translation: "Lock the cellulite problem."

Extract 23: “ลดเลือนริ้วรอยแห่งวัย" (Slight, treatment program; Slimming, November 2008: 73)

Translation: "Reduce aging wrinkles"

\section{Presupposition manipulation}

Presupposition is a prior assumption about the world or background belief or knowledge implicated by an utterance. Presupposition manipulation can be used as a strategy to implicate implicit knowledge or concepts without apparently mentioning them. It is found that in some of the advertisements, presupposition is manipulated in order to imply that some features are undesirable.

Extract 24: ใครว่า “ผิวแตกลาย รักษาไม่ได้" (Siam Laser Clinic, Slimming, December 2008: 33)

Translation: Who says "wrinkled and chapped skin cannot be cured"?

This sentence is a rhetorical question presupposing that wrinkled and chapped skin is something needing to be cured. Further, the verb รักษา 'to cure' implies that wrinkles and chapped skin is construed as an ailment or a problem.

Extract 25: “ผมขาวแก้ได้”... โดยไม่ต้องโกรกย้อม “ปิดผมขาวได้" ตั้งแต่แรกที่ใช้ (Katherine, herbal 
shampoo, Sukkhaphap Dee (สุขภาพดี), December 2008)

Translation: "Grey hair can be treated (repaired)" ... without the need to dye or tint. "Grey hair can be concealed" from the very first use.

In this extract, ผมขาวแก้ได้ 'grey hair can be treated' and ปิดผมขาวได้ 'grey hair can be concealed' presuppose that grey hair is a condition that needs to be treated and concealed. This implies that grey hair is a sign of aging and it is undesirable and troublesome.

Besides these two examples, it should be pointed out that the emphasized text in extracts $16,17,19,20,21,22,23,26,27$, 28 and 29 also exemplify the uses of presupposition manipulation. That is, in extracts 16, 17, 22 and 27 , it is presupposed that a sagging and drooping bust as well as cellulite are problems to be fixed, locked, and subdued. Extract 19 presupposes that aging wrinkles is the cause of anxiety and thus it is an undesirable thing that one wants to farewell. In extracts 20 and 21, wrinkling process and cellulite accumulation are presupposed to be unfavorable processes in need of suspension. In extract 23, aging wrinkles are presupposed unwanted marks to be reduced. Extract 26 presupposes that fat is something to be fought with. Likewise, in extracts 28 and 29, it is presupposed that the process of aging as well as skin problems are things to be resisted and overcome.

\section{Metaphor}

It is evident that WAR metaphors are used in advertisements of products and services for women in order to conceptualize natural conditions such as being overweight, having a blemished complexion, or aging as a martial enemy. Women with these conditions are positioned in a metaphoric battle against these enemies as suggested by the use of verbs denoting 'fighting.'

Extract 26: "Fighting Fat" (Double Impact; weight losing product, Slimming, December 2008: 2-3)

Extract 27: “สยบปัญหาเซลลูไลท์” และฟื้นฟูสภาพผิว (Lifetech Srim: weight losing program, Slimming, December 2008:53)

Translation: "Subdue cellulite problems" and resuscitate skin condition.

Extract 28: “ต่อต้านความชรา" (Reju Asoke, Health Plus, Nobember 2008: 9)

Translation: "Resist the process of aging." (Anti-aging)

Extract 29: ...วันนี้เราลองไปล้วงความลับของคุณนุ่น กันดูว่าทำอย่างไรเธอถึง "เอาชนะปัญหาผิวพรรณที่สาวๆ หลายคนพ่ายแพ้มานักต่อนัก" (Vite Secret, Health Plus, June 2008: 18-19)

Translation: ...Today, we will try to disclose Khun Noon's secret of why she has been able to "overcome a skin problem that has defeated several women."

\section{Intertextuality}

According to Fairclough (1992b, 1995), intertextuality refers to the condition 
whereby all communication events draw on earlier events. A form of intertextuality is interdiscursivity which occurs when different discourses and genres are articulated together in a communicative event. As for the advertisements of products and services for women, intertextuality is created by the insertion of other texts, mainly personal narratives and scientific facts in the larger frame of the advertising text. It is found that in some advertisements personal narratives are inserted to describe the depressive experience and the anxiety caused by some conditions construed as problematic such as being overweight, having wrinkles, and having unclear skin. These narratives attest to the fact that the stated condition(s) are really a problem as demonstrated below.

Extract 30: ช่วงปลายปี 47 “ดิฉันประสบปัญหาสิว อักเสบอย่างมาก ทั้งเจ็บ ทั้งอาย ไม่กล้าพบปะผู้คน" ไม่เคย คิดมาก่อนว่าผลิตภัณฑ์สมุนไพรจะช่วยเราได้ แต่พอใช้ได้ ผลด้วยตนเอง จึงหันมาศึกษาด้านสมุนไพรอย่างจริงจังและ ทุกครั้งที่พบคนที่มีปัญหาผิว จึงอยากแนะนำให้เขาดีขึ้น เหมือนกับเราค่ะ” วริศรา ประสมทรัพย์, เจ้าของผลิตภัณฑ์ว ริษา (Warisa herbal product, Sukkhaphap Dee (สุขภาพดี), June 2008: 11)

Translation: Around the end of 2004, "I experienced a serious outbreak of inflammatory acne. It was both painful and shameful. I dared not face people." I had never thought that herbal products could help me. However, after I successfully tried it, I studied herbs seriously. And every time I meet people with a skin problem, I want to advise them so that they may recover like myself. Warisra Prasomsap, the owner of "Warisa" herbal products.
In this example, a narrative is inserted about a miserable experience caused by inflammatory acne. By using the phrase "a serious outbreak of inflammatory acne problem," inflammatory acne is presented as a very significant problem. This problem caused two negative results for the narrator. First, the acne caused pain. Next and seemingly more important, it made her feel ashamed and she did not dare to meet people. It can be construed from this narrative that to confidently interact with people, one needs to be good looking. Those with an undesirable appearance may not feel confident enough to face and interact with others.

Concept 3: Bodily management can be done effortlessly and effectively owing to the miraculous power of the products and services for women's health and beauty. Women should improve themselves to be new and better persons by selecting the right products and services for themselves.

The linguistic devices used in representing this concept include lexical selection, overstatement and intertextuality as shown below.

\section{Lexical selection}

Lexical choices related to the construction of this idea can be categorized into three groups. Words or phrases signifying ease, short period of time, and effectiveness are selected to describe bodily improvement. Also, words denoting "secret" or "tips" are used to implicate that the right solutions of bodily improvement exist. 
Using lexical choices denoting "ease" and "short period of time"

The words or phrases denoting "ease" and "short period of time" are selected to represent the idea that bodily improvement can be done effortlessly. The following extracts demonstrate the use of these lexical choices.

Extract 31: “ลดเอว สะโพก ต้นขา 4 นิ้ว ใน 90 นาที" (Body Slender Package Program, Slimming, December 2008: 31)

Translation: "Reduce the size of waist, hip, and thigh by 4 inches in 90 minutes."

Extract 32: นวัตกรรมใหม่แห่งการปรับสีผิวให้ขาวอม ชมพู ดูสุขภาพดีอย่างเป็นธรรมชาติ... "ขาวอมชมพู...แบบ กะทันหัน" (Body Magic Magical White, Slimming, December 2008: 53)

Translation: New innovation in skin treatment makes your skin rosy white with a natural healthy look. Your skin will "become rosy white in a blink."

Extract 33: นวัตกรรมใหม่ล่าสุดแห่งปี ที่รวม 3 พลัง อันทรงประสิทธิภาพไว้ใน 1 เดียวให้คุณ “ผอมเพรียวได้ ภายใน 24 ชั่วโมง" (Power 3; weight losing program, Health Plus, April 2009: 12-13)

Translation: Latest innovation of the year which combines three in one power makes you "slender in 24 hours."

Extract 34: “หุ่นดี ทันใจไม่ต้องรอ” ด้วย 2 สุดยอด เทคโนโลยี (Siam Laser Clinic; Slimming, November 2008: 11)

Translation: Get "good shape instantly" by using 2 cutting edge technologies
Extract 35: “ผิวสวยชั่วข้ามวัน ขจัดไขมันชั่วข้ามคืน" กับโปรแกรมดีท็อกซ์ที่ $\mathrm{S} \quad(\mathrm{S}$ Medical $\mathrm{Spa}$, Slimming, October 2008: 52)

Translation: "Get beautiful skin in one day, rid yourself of cellulite in one night" by using D-Tox program at S Spa.

Extract 36: “แก้ไขริ้วรอยบนใบหน้า และยก กระชับใบหน้าที่หย่อนคล้อยได้ในทันที" (Nasha, Health Plus, September 2008: 25)

Translation: "Fix wrinkles and firm a drooping face instantly."

The use of words and phrases denoting 'ease' and 'short period of time' implies the miraculous power of the products and services. That is, they demonstrate the miraculous power of the products and services for women.

\section{Using lexical choices denoting "effectiveness"}

The words and phrase denoting favorable results or effectiveness such as เลือกได้ 'that you can select', สั่งได้ 'that you can order/design', กำหนดได้ 'that you can determine' อย่างเป็นธรรมชาติ 'look naturally, อย่าง ใจปรารถนา 'as you desire', อย่างมหัศจรรย์ 'miraculously' are used to represent the notion that bodily improvement can be done effectively. The following extracts demonstrate the use of these terms.

Extract 37: “ผอมเลือกได้" (Body Lift Up, Slimming, October 2008:109)

Translation: "Slenderness that can be designed" 
Extract 38: $\mathrm{AFC}$ “ผิวสวย...สั่งได้” $(\mathrm{AFC}$ Vitamin Rose Series, Health Plus, January 2009)

Translation: AFC "beautiful skin that can be ordered."

Extract 39: “ความขาวใส...ที่คุณกำหนดได้” $(\mathrm{Nu}$ Vite, Health Plus, April 2009: 2)

Translation: "Radiance... that can be determined."

Extract 40: นวัตกรรมจากนาโนเทคโนโลยี เพื่อปรับ สภาพผิวให้ "ขาวใสอย่างเป็นธรรมชาติ" (Porschy Perfect Serum, Slimming, December 2008: 8-9)

Translation: Nanotechnology for "natural skin whitening."

Extract 41: สารสกัดจาก Hyaluroonic Acid เพิ่มความชุ่มชื้นให้กับผิวเพื่อผิวที่ “สดใสเต่งตึงอย่างเป็น ธรรมชาติ” (Porschy Perfect Serum, Slimming, December: 8-9)

Translation: Hyaluroonic Acid extracts help increase moisture in the skin in order to "achieve a natural glow and firmness."

Extract 42: เปลี่ยนรูปลักษณ์ใหม่ของคุณได้ตั้งแต่วันนี้ "ดูดี สุขภาพดี ตลอดไปอย่างที่ใจปรารถนา" (Diet Now, miracle dietary (อาหารมหัศจรรย์), Sukkhaphap Dee (สุขภาพดี), July 2008: 81)

Translation: You can change your appearance from today onward. "Look good, feel healthy forever as you desire."

Extract 43: Boo-BenLarge ครั้งแรกกับ... “มหัศจรรย์”แห่งครีมกระชับและขยายขนาดทรวงอก (เผย ผลลัพธ์ภายใน 7 วัน) วิธีที่เป้ยใช้เนี่ยทั้งง่าย สะดวก "เห็นผล
อย่างมหัศจรรย์ทันใจ”แบบนี้

(Boo-BenLarge:

Breast Enhancer Cream, Slimming, December 2008: 19)

Translation: Boo-BenLarge, for the first time, the "miracle" breast enlargement and firming cream. (Results can be seen within 7 days.) The method I selected is easy, convenient, and "miraculously and instantly effective."

\section{Using the terms denoting "secret" and "tips"}

To successfully change or manage one's undesirable body, one needs to know special tips or secrets. The strategy used to convey this concept is the use of terms such as ความลับ 'secret', เคล็ดลับ 'tips' and รหัสลับ 'confidential code'. These terms suggest that information about the powerful product and service are secrets one needs to know in order to have a desirable appearance. Interestingly, these secrets are publicly disclosed to readers of the advertisements in order to enable them to correctly select the right product and service for themselves.

Extract 44: “รหัสลับ”...เพื่อการกระชับเฉพาะที่ (Shaper Firm and tone serum for Cellulite Management, Slimming, December 2008: 4-5)

Translation: "Confidential code"... for specific area firming

Extract 45: รูปร่างดี ต้องมี "เคล็ดลับ" (Slimming Plus Institution; Slimming, December 2008: 13)

Translation: To have a great body, one needs to know "the secrets." 
Extract 46: “เคล็ดลับ”ความเซ็กซี่ ที่การันตีโดยสาว ฮอต“เป้ย ปานวาด" (Boo-BenLarge, Slimming, October 2008: 84)

Translation: "Secrets to looking sexy" guaranteed by Pey Panwad, a hot celeb.

Extract 47: “ไขความลับผิวสวย" ด้วยสารสกัดจาก ยีสต์ดำ “เบต้ากลูแคน”เบต้ากลูแคน (B Glucan) ซึ่งสกัด จากยีสต์ดำ จะช่วยย้อนวัยให้อายุผิวถึง 10 ปี (B Glucan, Health Plus, October 2008: 25)

Translation: Unveil "the secret for beautiful skin" by ß Glucan, black yeast extract. B Glucan, black yeast extract, can rejuvenate the skin to look 10 years younger.

\section{Overstatement}

In some advertisements, overstatement is used to describe the effortlessness and effectiveness of bodily improvement.

Extract 48: “แก้ไข"ริ้วรอยบนใบหน้า และยกกระชับ ใบหน้าที่หย่อนคล้อย “ได้ในทันที” รู้จัก NASHA “สวย ได้ทันใจอย่างเป็นธรรมชาติ" ผิวสวย "ปราศจากริ้วรอยได้ ในทันที" ริ้วรอยตามธรรมชาติบนใบหน้าเกิดขึ้นตาม กาลเวลา สามารถ “แก้ไขได้ในทันที" ด้วย Nasha Technology ซึ่งสามารถเข้าไปช่วยเติมเต็มเนื้อเยื่อใต้ ผิวหนัง... “ให้คุณสวยในทันทีได้อย่างเป็นธรรมชาติ" (Nasha, Health Plus, September 2008: 25)

Translation: Repair wrinkles on your face, firm sagging and drooping face "in a blink." Learn more about Nasha then you "will instantly become naturally beautiful." "Your skin will become beautiful and wrinkle-free immediately." The wrinkles on your face caused by passing time can be "immediately fixed" by
Nasha technology which will improve underneath tissues... "making you become instantly and naturally beautiful."

Extract 49: “คืนชีวิตใหม่...ให้ตัวคุณ”เลิกวุ่น...กับ ส่วนเกิน "ตลอดไป" (Mind \& Care, diet program, Sukkhaphap Dee (สุขภาพดี), June 2008: 53)

Translation: "Regain a new life for yourself." Stop being concerned about cellulite problems "forever."

These two examples demonstrate the way overstatement is used to heighten the miraculous power of products and services for women's health and beauty. In extract 44 , the speed of the treatment process is overstated. Likewise, in extract 45 , the result of using the diet program is exaggerated.

\section{Intertextuality}

\section{Inserting personal narratives}

In addition to the strategies outlined, personal narrative is also used as a means to suggest the "right" product or service for consumers. These narratives are mostly in the format of problem-solution pattern (Hoey 1979, 1983). That is, they present a situation and problems the narrators faced. Then they reveal the ways in which the narrators responded to the problemmostly by using the advertised product or service. Finally, the result or evaluation of the solution is presented. These narratives serve as empirical evidence to suggest to the readers that the advertised products and services are the right choices.

Extract 50: “มื่อก่อนมีน้ำหนัก $98 \mathrm{Kg}$. รู้สึกว่า ตัวเองไร้ค่า ไม่เป็นที่ต้องการของใคร” ทำอะไรไม่คล่องตัว 
ดิฉันจึงพยายามลดน้ำหนักด้วยการอดอาหารมื้อเย็น 2 เดือน ต่อมาน้ำหนักลดไป $5 \mathrm{~kg}$. ดิฉันรู้สึกว่ามันไม่ทันใจเลย ตัดสินใจอดอาหารทุกมื้อ โดยทานเฉพาะส้มและน้ำเท่านั้น น้ำหนักดิฉันลดลงไปอีก $3-5 \mathrm{~kg}$. แต่ร่างกายดิฉันกลับไม่ มีแรง สมองเบลอไม่สามารถรับรู้อะไรได้เหมือนเก่า และ เป็นลมหมดสติบ่อยมาก จนมาวันหนึ่งเพื่อนได้แนะนำ ผลิตภัณฑ์ตัวนี้ให้ ดิฉันจึงได้ดื่มผลิตภัณฑ์ตัวนี้หลังอาหาร ทุกมื้อ น้ำหนักตัวของดิฉันค่อยๆ ลดลง ร่างกายแข็งแรงขึ้น สมองปลอดโปร่งขึ้น หน้าตาสดชื่นขึ้น เพราะดิฉันไม่ต้อง อดอาหารเหมือนเมื่อก่อน น้ำหนักดิฉันลดลงจาก $98 \mathrm{~kg}$. เหลือ $59 \mathrm{~kg}$. โดยไม่ต้องอดอาหาร ไม่ต้องพึ่งยาลดความ อ้วนอย่างคนอื่นๆ ดิฉันต้องขอบคุณเพื่อนๆ ที่ แนะนำ ผลิตภัณฑ์ที่ดีนี้ให้ดิฉัน “ผลิตภัณฑ์นี้ดีที่สุดจริงๆ ค่ะ"

(รุ่งรัตน์ ไชยภักดี) (Nature Gift coffee, Slimming, December 2008: 137)

Translation: "Previously, I weighed 98 kilograms. I felt that I was worthless and undesirable in the eyes of everyone." It was too clumsy to do anything. So I decided not to eat dinner in a drastic attempt to lose weight. Two months later, I lost 5 kilograms. I still felt that the result was not satisfactory enough. So, I decided to cancel every meal and to eat only oranges and water. My weight was reduced another 3-5 kilograms. However, I felt fatigued. My brain could not function normally. And I often fainted. It wasn't until one day that my friend introduced this product to me. I then tried drinking this product after every meal. My weight gradually decreased and I became healthier. Now, my brain functions more productively. I look more refreshed because I do not have to go on a diet like before. My weight has reduced from 98 kilograms to 59 kilograms without taking any diet control pills like other programs. I have to thank my friend for introducing this product. "This product is the best one for me." (Rungrat Chaiphakdee )

\section{Citing scientific facts}

Scientific facts are authoritative as they are systematically and objectively proven. The insertion of text about scientific and empirical knowledge in the advertisements helps "verify" that the advertised products and services are the right ones for women.

Extract 51: เพื่อผู้หญิงวันนี้ ผลิตภัณฑ์สลิมคัพ For Lady ผสมสารสกัดที่เป็นประโยชน์ และมีคุณค่า ตามที่ผู้หญิงทุกท่านต้องการ “ผสมคอลลาเจนช่วยบำรุงผิว ให้กระชับ ชะลอการเกิดริ้วรอย ช่วยซ่อมแซมคอลลาเจนที่ ผิวทำให้การยืดหยุ่นของผิวดีขึ้น เพิ่มความชุ่มชื้นและเต่งตึง ขึ้น โปรตีนจากถั่วเหลืองมีฮอร์โมนที่มีชื่อว่า“ไฟโตเอสโต รเจน" ซึ่งมีคุณสมบัติเช่นเดียวกับฮอร์โมนเอสโตรเจนอย่าง อ่อนๆอันเป็นฮอร์โมนที่สำคัญของผู้หญิง ซอยไอโซฟลา โวนส์ ช่วยให้ผิวพรรณเปล่งปลั่ง สดใส" (LIFETECH SRIM CUP Instant coffee for health, Slimming, November 2008: 33)

Translation: For today'swomen, Srim Cup For Lady has added useful extracts that every woman needs. "Collagen helps nourish and firm your skin and slow down the wrinkling process. It also helps repair collagen tissue making the skin plump, firm, and refreshed. Soy protein contains phytoestrogen hormone which has the same quality as light estrogen hormone, a vital hormone for women. Soy Isoflavone helps make the skin bright and radiant."

In this advertisement, scientific facts about collagen, soy protein, estrogen and soy isoflavaone are inserted in order to suggest that this coffee is the right product for women. 


\section{The social practice: Manipulative attempts to influence women's cognition and behaviors}

The advertisements for products and services for women in Thai health and beauty magazines are part of the trend health concerns in contemporary Thai society. The production and distribution of these advertisements is inevitably influenced by trends. The analysis in this study reveals that an ideology intensively conveyed in these advertisements is the ideology femininity. In this way, they can be construed as texts of the discourse of femininity.

According to Foucault (1972a, 1972b), discourse is the system or process which constitutes the identities and significances for things surrounding it. In accordance with Foucault, in this present study, it is found that the discourse of femininity in the advertisement of products and services for women in Thai health and beauty magazines constitutes the identity of 'desirable' women. Namely, those with appealing physical appearances-slim and slender figure, youthful appearance, white, clear, and radiant skin, large and firm bust, and odorless privates - are construed 'desirable.' By contrast, those whose appearance differs from the "ideal" models are construed as "undesirable" people although their appearance is in fact natural. The advertisements attempt to persuade those who do not have 'desirable' appearances to believe that they are in trouble and cannot be fully confident. Consequently, these people should react by managing their bodily condition in order to get rid of their problems and anxieties. Moreover, change or body management can be done effortlessly and effectively with the miraculous power of the advertised products and services. According to this ideology, ideally, women should not simply limit their satisfaction to their current condition. They should try to become 'beautiful' and 'desirable.' This concept is in accordance with the slogan of a cosmetics' television commercial. It says ผู้หญิงอย่าหยุดสวย 'women must not stop being beautiful.'

From Van Dijk's (2006) point of view, the production and distribution of these advertisements which implicitly convey this ideology of femininity is a form of manipulation. That is, the manufacturers and service providers make use of their access to media in order to discursively construct a set of ideas about 'desirable and undesirable women' in order to eventually benefit themselves. The ideology represented in the advertisements and distributed in the magazines can be considered an attempt to pervasively influence the cognition of consumers and persuade them to change or manage themselves in "desirable ways" which have been designed by the manufacturers and service providers.

Moreover, the concept that transformation into a 'desirable' woman can be done effortlessly and effectively owing to the miraculous power of the products and services seems to suggest that women should continue working on their seemingly never ending project of body improvement. Eventually, those who profit most from these projects to achieve 'desirable' body conditions are the manufacturers and the service providers. Additionally, the tempting brand names of some products and services such as Srim Cup, Golden Life Coffee Srim, Nu Vite, Vite Secret, Boo-BenLarge, Cellu Loss Sculptor, Slend Detox Fiber and REJU ASOKE demonstrate another way in 
which the manufacturers and service providers make use of this concept of 'desirable' bodily features.

Last, the ideology of femininity represented in these advertisements is significantly different in two ways from the traditional concepts of desirable women portrayed in conventional Thai texts such as literature, textbooks, and proverbs. First, the ideology represented by these advertisements mainly highlights the importance of physical body conditions. The intellectual and behavioral aspects are noticeably ignored. Next, the concept of taking care of oneself in order to become healthily beautiful seems to mainly and solely focus on an individual self. Issues of social interrelations and interaction that might be expected from a 'desirable' woman, such as being a good housewife, taking good care of her family, helping other people, are not mentioned. The relations between an individual woman and others revealed in these advertisements is that the woman is an object of gaze for others, and for men in particular. A woman who is desirable should be attractive looking in order to impress others and to maintain a good level of selfesteem.

To sum up, this ideology creates a definition of "desirable" women which is mainly based on female bodylore. Some features of these "desirable" women differ noticeably from those stated earlier in conventional discourses in Thai society.

\section{Conclusion}

This paper has aimed to answer two research questions, namely 1) what is the ideology of femininity represented in advertisements for products and services for women in Thai health and beauty magazines? and 2) what are the linguistic strategies used to represent these ideological concepts?

It is found that these advertisements convey an ideology of 'desirable women' which consists of three related concepts.

1) Desirable features for women are a slim and slender figure; youthful appearance; white, clear, and radiant skin; large, firm, and shapely bust; and odorless privates. These features are construed signs of "healthy beauty." These "desirable" features are what every woman would like to have.

2) Some natural bodily conditions which are opposite to the desirable features are problems, and enemies. Women with these "problems" are in trouble and lack confidence.

3) Bodily management can be done effortlessly and effectively owing to the miraculous power of the products and services for women's health and beauty. Women should improve themselves to be new and better persons by selecting the right products and services.

In other words, these ideological concepts define the features of 'desirable women,' create anxiety for ordinary women and encourage these women to manage their body in order to become better and more desirable women. Body improvement is made possible by the advertised products and services. According to this ideology, it can be seen that all these 'desirable' features are merely physical. Intellectual and behavioral aspects, as promoted in some didactical Thai texts and proverbs, are ignored.

Various linguistic strategies are used to represent these ideological concepts 
including lexical selection, claiming common fact, metaphors, overstatements, rhetorical questions, presupposition manipulation, and intertextuality. Among these strategies, lexical selection is the most widely employed. There are several subtypes of lexical selection found in this study such as using positive words to ratify features to be construed as 'desirable,' using negative words to negate 'undesirable' features,' using a newly coined phrase สวย สุขภาพดี 'healthily beautiful' to denote 'a desirable' condition, and using terms denoting problems and anxiety to signify 'undesirable' conditions.

The findings of this study demonstrate one of the roles of language in the social construction of gender ideology in contemporary Thai society. That is, linguistic strategies serve as a significant means for constructing and representing concepts and images of 'desirable' women to be distributed in health and beauty magazines.

According to de Beauvoir (1952), women are not born but rather become women. Various social and cultural institutions, especially the media, shape concepts of how to become women, particularly 'desirable' women, for members of a society (West and Zimmerman 1987, Kaewthep 2000, Lorber 2003, Andersen 2006; Barker 2008). As for the present study, it is found that the advertisements in health and beauty magazines can be construed attempts to provide some female members of contemporary Thai society with ways of becoming 'desirable' women. Unsurprisingly, this definition and practices ultimately profit the manufacturers and service providers. Namely, these advertisements attempt to make women believe that to become สวย
สุขภาพดี 'healthily beautiful', they need to select the right and effective products or services. This ideology presupposes that women have to pay and consume in order to become 'desirable.'

Last, it is anticipated that this study will lead to an increased awareness of the discursive manipulation manufacturers and service providers. Ultimately, it is hoped that this awareness will allow women to realize that they are all beautiful and they can maintain a good level of self-esteem in their own ways which may differ from the 'desirable' ways presented by advertisements in the health and beauty magazines.

\section{References}

Anansuchatkul, Hataya. 2001. Representations of Thai Identity in the Context of Globalisation: A Linguistic Approach to Analysing the Discourse of Thai Identity in Advertisements. Paper presented at the 8th International Conference on Thai Studies, Nakhon Phanom. January 9-12, 2001.

Andersen, Margaret L. 2006. Thinking about Women: Sociological Perspectives on Sex and Gender. Boston: Pearson.

Baudrillard, Jean. 1999. The Consumer Society: Myths and Structures. London: Sage.

Barker, Chris. 2008. Cultural Studies: Theory and Practice. Los Angles: Sage.

Bernstein, D. 1974. Creative Advertising. London: Longman. 
Blommaert, Jan. 2005. Critical Discourse Analysis. In Discourse: A Critical Introduction, pp. 21-38. Cambridge: Cambridge University Press.

Cook, Guy. 1992. The Discourse of Advertising. London/ New York: Routledge.

Calasanti, Toni, and Neal King. 2007. "Beware of the estrogen assault": Ideals of old manhood in anti-aging advertisements" Journal of Aging Studies.

Chaisingkananont, Somrak. 2001. Rotniyom: Phasa Nai Songkhom Thai Yuk Boriphokniyom (Taste: Language in Consumeristic Thai Society). Bangkok: Social Research Institute, Chulalongkorn University. (trans.)

Chaudhuri, Maitrayee. 2001. Gender and Advertisement: The Rhetoric of Globalisation. Women's Studies International Forum, 24, 3.4: 373 385.

Choosaengsri, Pimruthai. 1991. Women's Concepts in Women's Magazines 1957-1973. M.A.'s thesis, Thammasat University. (trans.)

Crawshaw, Paul. 2007. Governing the healthy male citizen: Men, masculinity and popular health in Men's Health magazine. Social Science \& Medicine. 65.8: 1606-1618.

de Beauvoir, Simone. 1952. The Second Sex. Trans. H.M. Parshely. New York: Abfud \& Knopf.

Fairclough, Norman. 1989. Language and Power. London/ New York: Longman.
---. 1992a. Discourse and Social Change. Cambridge: Polity Press.

---. 1992b. Intertextuality in Critical Discourse Analysis. Linguistics and Education 4: 269-293.

---. 1995. Critical Discourse Analysis: The Critical Study of Language. London and New York: Longman.

Foucault, Michel. 1972a. Politics and the Study of Discourse. In The Foucault Effect: Studies in Governmentality, eds. Graham Burchell et. al. pp. 53-72. Chicago: The University of Chicago Press.

---. 1972b. The Archaeology of Knowledge and the Discourse on Language. New York: Pantheon Books.

Hoey, Michael. 1979. Signaling in Discourse: Discourse Analysis Monograph 6. Birmingham: English Language Research, Birmingham University.

---. 1983. On the Surface of Discourse. London: Allen and Urwin.

Hongladarom, Krisdawan, and Soraj Hongladarom. 2006. Discourse and the Southern Region and Violence in Thai Society) In Mong Sangkhom Phan Wathakatm (Watching the Society through Discourse). Krisdawan Hongladarom and Janthima Iamanond, eds. pp. 103-134, Bangkok: Chulalongkorn University Press. (trans.)

Hongladarom, Krisdawan. 1996. Us and Them in Thai Society: A Study of the News Presentation of Hill Tribe People in Thailand, Warasan Aksonsat 
Silpakorn (Silpakorn's Journal of Arts). (trans.)

---. 2000. Competing Discourses on Hilltribes: Media Representation of Ethnic Minorities Thailand. Manusya: Journal of the Humanities 3.1: 1-19.

Kaewthep, Kanjana. 2000. Essays on Women and Media. Bangkok: Thammasat University Press. (trans.)

Kanjanaurairoj, Chanunshee. 1995. A Study of Women's Image in Daily Newspapers during1985-1994. M.A.'s thesis, Chulalongkorn University. (trans.)

Khananurak, Mallika. 1981. Kan Chom Khwamngam Khong Nang Nai Wannakhadee Thai (The Laudation of Women's Beauty in Thai Literature). Pattanee: Department of Thai and Eastern Languages, Faculty of Humanities and Social Sciences, Prince Songkhla University. (trans.)

Liwcharoenchai, Yapa . 2004. A Discourse Analysis of Quizzes in Thai Magazines. M.A.'s thesis, Faculty of Arts, Chulalongkorn University. (trans.)

Lorber, Judith. 2003. "The Social Construction of Gender" In The Social Construction of Difference and Inequality: Race, Class, Gender, and Sexuality. $2^{\text {nd }}$ edition. Ed. Tracy E. Ore, pp. 99-106. New York: McGraw Hill.

Panpothong, Natthaporn. 2007. Being unattractive is like having a disease: on the advertising discourse of cosmetic surgery in Thai. Paper presented at the International Symposium on Discourse, Communication, and Modernity.
September 7, 2007. Bangkok, Thailand.

Phakdeephasook, Siriporn. 2007. “A Smart Person Knows How to Consume Healthily: A Study of Advertising Discourse on Health Products and Services." A paper presented at the International Symposium on Discourse, Communication, and Modernity. September 7, 2007. Bangkok, Thailand.

Pongudom, Ratchanin. 2005. The Relation between Language and Values on Beauty: A Study of Advertising Discourse on Cosmetics in Thai. M.A.'s thesis. Chulalongkorn University, Thailand. (trans.)

Ponprateep, Kanchanaporn. 2000. The Logics of Consumption in the Advertisement of Health-Claimed Food Supplements. M.A.'s thesis. Thammasat University, Thailand. (trans.)

Sawasburi, On-anong. 1989. Life Question-and-Answer Column in Magazines in the Reflection of Thai Women's Role and Status. M.A.thesis. Chulaonlongkorn University

Soden, Shakuntala Rudra (Satori). 2008. Yummy Grannies: Myths of Ageing in Women's Magazine. A paper presented at the $17^{\text {th }}$ Sociolinguistics Symposium: Micro and Macro Connection, April 3 5, 2008. Amsterdam, the Netherlands.

Thamsarnsunthon, Jitraporn. 1994. Values and Attitude on Gender as Reflected in Women's magazines. M.A.'s thesis, Faculty of Communication Sciences, Chulalongkorn University. (trans.)

Williams, Raymond. 1980. Advertising: The Magic System. In Problems in 
Materialism and Culture, pp. London: New Left Books.

Williamson, Judith. 1978. Decoding Advertisement: Ideology and Meaning in Advertising. London: Marion Boyars.

Wodak, Ruth. 1995. "Critical linguistics and critical discourse analysis". In Handbook of Pragmatics, Eds, Jef Verschueren, Jan-Ola Östman, Jan Blommaert and Chris Bulcaen. Amsterdam: John Benjamins, 204210.

Van Dijk, Teun A. 1993. Principles of Critical Discourse Analysis. Discourse and Society 4.2: 249-283.

---. 2003. Critical Discourse Analysis. In The Handbook of Discourse Analysis. Eds. Deborah Schiffrin et al. pp. 352-71, Malden, M.A.: Blackwell.

---. 2006. Discourse and Manipulation. Discourse and Society Vol. 17.3: 359-383.

West, Candace, and Don Zimmerman 1987. "Doing Gender," Gender and Society 1: 125-51.

Wongbiasaj, Soranee, Hatthaya Jantharamangkorn, Satanan Piangboontha. 2006. Awarded Children's Books: A Discourse and Literary Analysis, In Mong Sangkham Phan Wathakam (Looking into the Society through Discourses).

Krisdawan Hongladarom and Janthima Iammanond, eds, pp. 187-221. Bangkok: Chulalongkorn University Press. (trans.) 